\title{
PERENCANAAN RUANG PUBLIK DI AREA TEPI SUNGAI CISADANE
}

\author{
Imaniar Sofia Asharhani ${ }^{1}$, Anisza Ratnasari², Marchelia Gupita Sari ${ }^{3}$ \\ ${ }^{1,2,3}$ Program Studi Arsitektur, Universitas Pradita \\ imaniar.sofia@pradita.ac.id, anisza.ratnasari@pradita.ac.id, marchelia.gupita@pradita.ac.id
}

\begin{abstract}
Abstrak
Pemanfaatan RTH daerah sempadan yang rawan erosi serta peningkatan muka air yang terjadi secara berkala saat musim hujan merupakan tantangan yang sering terjadi di kota yang dilintasi sungai. Penataan daerah sempadan sungai antara dapat difungsikan menjadi zona budi daya (UU No 5 Tahun 2008). Zona tersebut dapat dimanfaatkan sebagai kegiatan-kegiatan masyarakat sekitar area tersebut. Perlu perencanaan yang baik agar kegiatan yang ada tidak menimbulkan dampak merugikan bagi kelestarian dan keamanan fungsi serta fisik sungai. Di sisi lain, perencanaan tersebut harus tepat sasaran agar dapat digunakan secara maksimal oleh masyarakat, sebagai bentuk fasilitas kota agar kegiatan berkota dapat terwujud.

Metode yang digunakan dalam pelaksanaan kegiatan ini adalah metode deskriptif melalui pemetaan lokasi sekitar untuk mengetahui sasaran desain sebagai kriteria awal. Dari kriteria tersebut akan diterjemahkan kedalam desain yang ideal untuk suatu ruang public dengan diskusi internal bersama anggota tim pengabdi. Setelah itu, pengembangan desain awal akan disesuaikan dengan batasan kondisi fisik dan realisasi pengerjaan dengan pentahapan pembangunan. Dengan metode ini, diharapkan masyarakat sekitar sungai Cisadane, khususnya masyarakat yang tinggal dekat dengan lokasi perancangan akan dapat menggunakan fasilitas tersebut secara maksimal. Realisasi ruang publik tahap awal tersebut diharapkan dapat memicu perencanaan ruang public yang ideal secara menyeluruh.
\end{abstract}

Kata Kunci : ruang publik; sempadan sungai; warga permukiman

\section{PENDAHULUAN}

Area Gading Serpong, Tangerang merupakan kota satelit yang telah dikembangkan oleh Summarecon sejak tahun 2004, dan dinamakan dengan Summarecon Serpong. Area ini dilewati oleh Sungai Cisadane yang memberikan nuansa hijau sekitarnya. Saat ini Daerah Aliran Sungai Cisadane belum diolah dengan baik untuk masyarakat, sehingga masih sebatas area penghijauan. Konsep Ruang Terbuka Hijau atau di area tepian sungai Cisadane perlu dikembangkan untuk dapat dirasakan manfaatnya oleh warga.

Rancangan wilayah perkotaan dapat dikatakan berhasil jika mampu mengajak warganya untuk melakukan kegiatan berkota. Hak berkota dikembangkan berdasarkan asas kebersamaan, keadilan sosial, dan kesetaraan bagi semua warganya. Tidak terkecuali untuk anak-anak, orang lanjut usia, dan penyandang disabilitas. Perlu diberikan rangsangan agar seluruh lapisan mayarakat dapat berpartisipasi aktif dalam meningkatkan kualitas kehidupan kota yang berkelanjutan. Salah satunya ialah dengan mulai dikelolanya peningkatan kelengkapan serta kualitas sarana dan prasarana Ruang Publik di area tersebut. Salah satu sarana yang mendukung perkembangan sebuah kota terutama dalam meningkatkan aspek sosial yaitu Ruang Terbuka Hijau.

$$
\text { Lingkungan Hidup dan Bencana }
$$


Ruang publik adalah ruang yang dapat diakses oleh publik dan tempat dimana orang-orang untuk melakukan aktivitas secara individu maupun berkelompok.(Carr, 1992, p. 50 dalam ). Dengan adanya ruang publik maka interaksi sosial antar warga semakin aktif, sangat tempat interaksi masyarakat. Melihat potensi yang ada karena area dilaksanakannya pengabdian masyarakat ini berada di dekat perumahan dan dekat dengan akses Tol Serpong, maka sasaran proyek ruang public dapat berhasil. Harapan kedepannya, dengan adanya Ruang Terbuka Publik di salah satu area Tepi Sungai Cisadane dapat ditularkan area tepi sungai lainnya. Sehingga Kawasan Gading Serpong dapat memiliki ruang kota yang nyaman bagi warganya untuk berkegiatan di luar ruangan.

\section{RUANG TERBUKA PUBLIK TEPI AIR}

Kawasan tepi air merupakan area yang secara geografis berbatasan dengan air, misalnya daerah suatu kota yang menghadap ke laut, sungai, danau atau sejenisnya. Menurut Carr,1992, kawasan tepi air adalah area yang dibatasi oleh air dari komunitasnya yang dalam pengembangannya mampu memasukkan nilai manusia, yaitu kebutuhan akan ruang publik dan nilai alami. Keberhasilan utama dari upaya pengembangan kota tepi air ditentukan oleh bagaimana reaksinya terhadap kualitas karakteristik dan penyediaan ruang publik di tepi air (Sastrawati,2003 dalam Rezeki 2017).

Berdasarkan Permen PU No. 05/2008 Pemanfaatan RTH daerah sempadan sungai dilakukan untuk kawasan konservasi, perlindungan tepi kiri-kanan bantaran sungai yang rawan erosi, pelestarian, peningkatan fungsi sungai, mencegah okupasi penduduk yang mudah menyebabkan erosi, dan pengendalian daya rusak sungai melalui kegiatan penatagunaan, perizinan, dan pemantauan. Penataan daerah sempadan sungai antara lain berfungsi menjadi zona budi daya. Zona tersebut dapat dimanfaatkan kegiatan-kegiatan masyarakat sekitar salah satunya penyelenggaraan kegiatan-kegiatan yang bersifat sosial, keolahragaan, pariwisata dan kemasyarakatan yang tidak menimbulkan dampak merugikan bagi kelestarian dan keamanan fungsi serta fisik sungai dan danau.

Keberhasilan ruang publik dapat diukur dengan parameter yang dikembangkan oleh PPS
(Project for Public Space) untuk membantu masyarakat untuk mengevaluasi keberhasilan ruang public. Terdapat 4 faktor kriteria utama dalam menentukan kualitas ruang publik, yaitu aksesibilitas dan penghubung, kenyamanan dan citra, kegunaan dan aktivitas, serta interaksi social. Kemudahan akses untuk semua lapisan masyarakat termasuk yang memiliki keterbatasan fisik perlu untuk diakomodir. Ruang public sebagai simpul berkegiatan di ruang luar diharapkan dapat diwujudkan, antara lain dengan menawarkan desain yang sesuai dengan gaya hidup masyarakat sekitar. Selain itu keberadaan ruang public dapat menjadi tempat interaksi antar individu dan antar komunitas. Dengan menerapkan keempat kriteria sesuai Gambar 1, maka diharapkan kegiatan berkota oleh masyarakat dapat terwujud

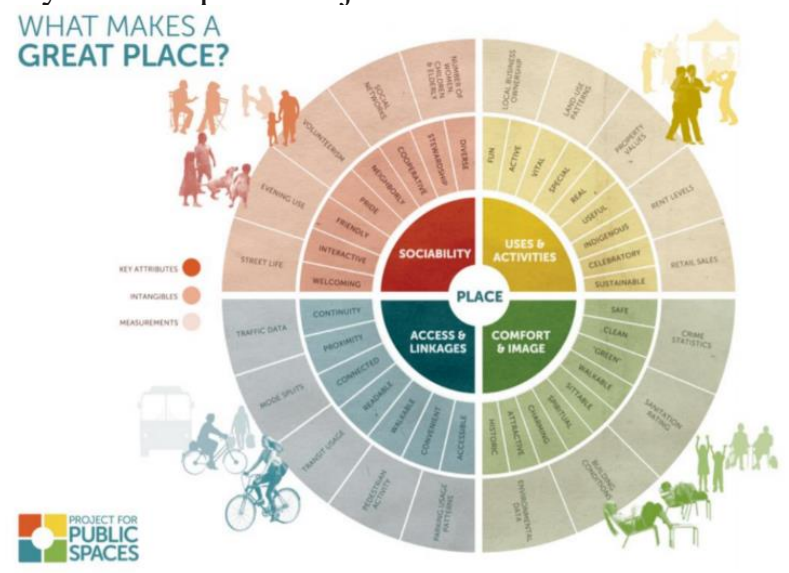

Gambar 1. Kriteria Penentu Kualitas Ruang Publik

\section{METODE}

Mengingat bahwa CSR adalah merupakan kewajiban yang harus dilaksanankan perusahaan sebagaimana amanat UU No 40/2007 bab V pasal 74, maka harus dilaksanakan dengan baik sehingga memberikan dampak positif bagi keberlanjutan perusahaan dimasa mendatang. Pola pikir inilah yang membuat manajemen CSR menjadi tidak sekedar Program Sosial, tetapi harus menjadi media marketing yang lebih efektif. Dosen dan mahasiswa Universitas Pradita sebagai rekanan dari Summarecon melaksanakan kegiatan non-fisik berupa ususlan desain perancangan. Dengan memberikan usulan desain Ruang Terbuka Hijau di tepi sungai, diharapkan perealisasian rancangan \begin{tabular}{l|l} 
Lingkungan Hidup dan Bencana & 634
\end{tabular} 
dapat sesuai dengan kebutuhan warga, Sehingga warga sekitar memiliki kesadaran atas hak mereka dalam menikmati Ruang Hijau di area tempat tinggal mereka. Metode pelaksanaan Pengabdian kepada Masyarakat (PkM) ini dilakukan dengan;

\section{a. Persiapan}

Pelaksanaan survei lapangan dan pemetaan sosial secara sederhana dapat dilakukan dengan pengamatan langsung. Survei lapangan dilakukan untuk mengidentifikasi batasan perancangan agar tidak melewati area sempadan seungai. Identifikasi ini dilakukan dengan cara pengukuran dan pencarian data sekunder tentang ketinggian muka air saat musim hujan. Tahap ini dilakukan untuk mencapai aspek aksesibilitas dan konektivitas (access \& linkage) dalam Kriteria Penentu Kualitas Ruang Publik sesuai Gambar 1.

Pemetaan sosial dilangsungkan secara singkat dengan membuat scenario kegiatan dan pemetaan kondisi sosial masyarakat di sekitar lokasi. Karena kondisi saat ini area tersebut tidak ada kegiatan masyarakat didalamnya, maka perlu dilaksanakan diskusi internal yang menghasilkan prediksi adanya ragam kegiatan yang mungkin berlangsung di area publik tersebut. Pada tahap ini diharapkan identifikasi sejumlah kelompok social dapat dipetakan untuk mendukung parameter keberhasilan ruang public yang ke-2, yaitu keramahan terhadap pengguna (sociable).

Setelah itu diskusi internal dilaksanakan, maka dilanjutkan dengan dilaksanakan FGD (Focus Group Discussion) bersama para warga yang menjadi sasaran pengguna ruang publik. Kesesuaian rancangan terhadap kebutuhan dan pengguna perlu diterjemahkan menjadi desain dengan perencanaan terukur. Tahapan ini mendukung parameter keberhasilan Kegunaan \& Aktivitas (Uses \& Activity). Mengingat kondisi naik turunya muka air sungai yang selalu berubah tergantung kondisi cuaca, batasan aktivitas juga perlu dipikirkan agar tetap aman. Banjir yang terjadi secara berkala perlu disiasati agar tidak membahayakan pengguna ruang public tepi sungai.

Usulan desain ideal dan mengeluarkan formulasi tema desain, sesuai kriteraia comfort \& image.
Dengan melihat adanya keterbatasan kondisi fisik, maka dapat dibuat usulan pentahapan desain, sehingga suatu ruang public mampu mewadahi berbagai masyarakat dari anak kecil dan keluarga, remaja dan komunitas, serta lansia. Aksesibilitas dan desain universal akan menjadi parameter untuk menentukan rancangan tahap awal tersebut.

\section{b. Pelaksanaan}

Tahap pelaksanaan akan diawali dengan melakukan pengukuran lapangan, persiapan dan pelaksanaan FGD bersama warga, menentukan desain yang sesuai dengan keinginan warga dan kondisi tapak, membuat rancangan pentahapan pembangunan, dan membuat detail desain di tahap awal. Serta memberikan keluaran berupa gambar skematik yang terukur. Detail Ukuran, Material, dan Vegetasi akan dapat keluar di tahap terakhir. Usulan ini nantinya dapat dipresentasikan sebagai bahan diskusi dan dapat dikembangkan oleh tim lapangan PT. Sumarecon Agung.

\section{c. Evaluasi}

Evaluasi dilakukan untuk mengukur tingkat penggunaan dan kemudahan akses di area perencanaan. Evaluasi yang akan dilakukan dalam bentuk pengamatan langsung dan wawancara yang dilakukan secara lisan dan informal setelah seluruh tahapan kegiatan terlaksana. Kegiatan PKM dilaksanakan secara bertahap, yaitu pekerjaan untuk aksesibilitas dan konektifitas, identifikasi kelompk social dan kebutuhan aktivitas warga sekitar sebagai sasaran pengguna ruang public dengan FGD, perencanaan desain ideal sesuai hasil diskusi, pekerjaan pembangunan ruang publik.

\section{HASIL DAN PEMBAHASAN}

Akibat adanya situasi pandemic Covid-19, maka kegiatan PKM CSR masih tertunda untuk keseluruhan rangkaian pelaksanaannya. Oleh karena itu, kegiatan yang sudah dilakukan ialah masih pada tahap awal, yaitu pekerjaan aksesibilitas dan konektivitas area tersebut.

\section{Persiapan}

Kegiatan Pengabdian kepada Masyarakat akan dilaksanakan pada area sempadan Cisadane selebar kurang lebih $1 \mathrm{~km}$. Lokasi dekat dengan Cluster Flourite Gading Serpong dengan alamat J1

$$
\text { Lingkungan Hidup dan Bencana }
$$


Raya Kelapa Gading Utara No 47, Pakulon Barat,, Kecamatan Kelapa Dua, Tangerang Banten. Dari diadakannya Pengabdian kepada Masyarakat (PkM) ini diharapkan desain yang telah dikembangkan oleh tim Pengabdi dapat diterapkan dan digunakan secara maksimal oleh warga sekitar. Area yang dipilih ditunjukkan dengan warna merah, yaitu berupa jalur hijau ditepi sungai Cisadane yang berbatasan dengan Jalan Raya Kelapa Gading Utara. Lokasi yang dipilih ini merupakan lokasi yang dekat dengan pintu gerbang Tol Tangerang kilometer 18 (gambar 2). Sehingga, dapat disebutkan daerah ini menjadi wajah kota Gading Serpong, khususnya bagi pendatang yang masuk dari arah gerbang Tol KM 18 tersebut. Area ini juga dekat dengan sabuk komersial berupa ruko-ruko di sepanjang jalan Boulevard Gading Serpong dan J1 Raya Kelapa Gading Utara.

Area ini berdekatan dengan Ruko Flourite dan berada di depan gerbang utama Cluter Perumahan Flourite. Sehingga sasaran pengguna salah satunya warga dari perumahan tersebut dan juga pengunjung di area komersial diseberangnya. Selain Cluster Perumahan Flourite, terdapat permukiman warga yang tidak jauh dari lokasi. Terdapat pula Sekolah Dasar Muhammadiyah 3 yang terletak di permukiman tersebut. Para siswa yang bersekolah di SD tersebut berpeluang besar untuk bias menjadi calon pengguna ruang public yang akan dibangun di sempadan sungai.

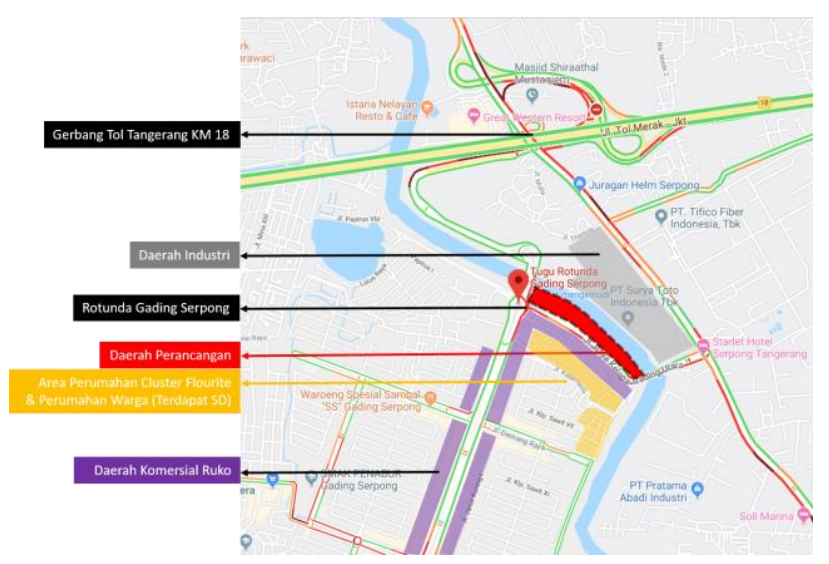

Gambar 2. Lokasi PkM, Tepi Sungai Cisadane
Tahap selanjutnya ialah kegiatan survei yang dilakukan dengan pengambilan gambar dan dilakukan pengukuran. Kondisi vegetasi yang ada di tepi sungai sudah baik dengan adanya pohon peneduh. Terdapat pohon trembesi yang berjajar sepanjang Jalan Raya Kelapa Gading Utara dan beberapa pohon perdu dan pohon pisang pada sekitar area. Kondisi sungai masih relative dangkal, sebab belum memasuki musim penghujan. Kondisi tanah berupa tanah basah seperti rawa-rawa, menandakan ketinggian air meningkat dan menutupi tanah tersebut dimusim penghujan. Pada sisi jalan raya, sudah terdapat saluran air dengan kondisi berlubang dan membahayakan apabila orang yang melintas. Pejalan kaki tidak dapat melintasi area tersebut kareana masih berupa tanah dan belum terdapat sarana perkerasan yang memadahi. Hanya terdapat kanstin untuk membatasi daerah lintasan kendaraan, dengan level ketinggan yang dibedakan dengan jalan aspal. Informasi ini diperlihatkan pada Gambar 3.

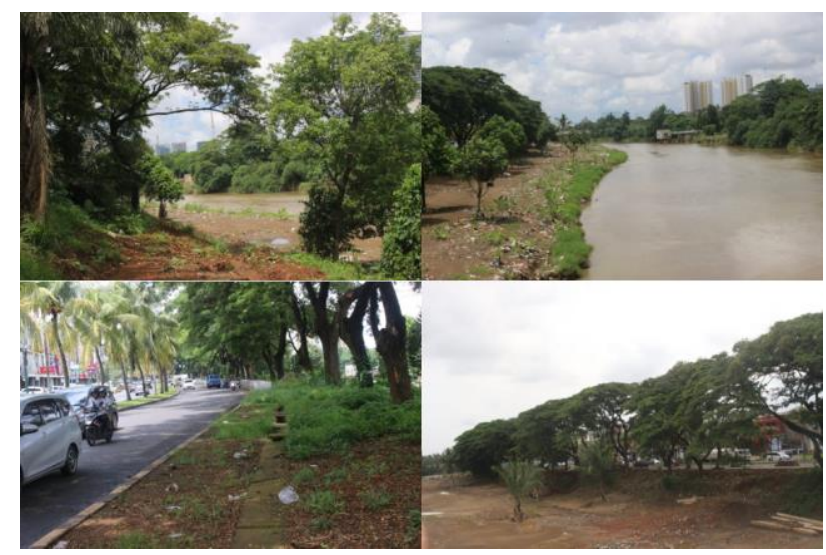

Gambar 3. Suasana di Lokasi, Tepi Sungai Cisadane

Aksesibilitas menjadi kriteria yang wajib diakomodir dalam perencanaan ruang publik. Penggunaan jalur sirkulasi harus dapat diakses secara universal oleh siapapun termasuk penyandang disabilitas. Oleh karena itu, penting untuk dilakukan studi literasi dimensi minimum untuk pengguna kursi roda, pengguna alat bantu jalan, pembawa kereta dorong utnuk bayi, pembawa binatang peliharaan, anak-anak dan lansia.

Persiapan selanjutnya ialah dilakukan diskusi bersama tim PkM untuk merencanakan 
kegiatan FGD (Focus Group Discussion) bersama warga. Tim PkM belum semuanya pernah memandu kegiatan FGD bersama warga, sehingga dilakukan simulasi FGD untuk melancarkan kegiatan. Pada proses latihan ini, dosen bertindak sebagai fasilitator, dan mahasiswa bertindak sebagai perwakilan warga. Pertama dilakukan identifikasi kebutuhan aksesibilitas dan konektivitas, kemudian pendataan ragam kelompok social yang menjadi target pengguna (Tabel 1). Pada tahap ini, fasilitator perlu menuliskan segala aspirasi yang dikeluargan oleh partisipan, sehingga seluruh anggota grup diskusi dapat melihat pemetaan hasil dan rangkuman poinpoin diskusi.

Tabel.1 Topik Diskusi

\begin{tabular}{|c|c|c|}
\hline No. & Kriteria & Diskusi Internal \\
\hline 1 & $\begin{array}{l}\text { Aksesibilitas } \\
\& \\
\text { Konektivitas }\end{array}$ & $\begin{array}{l}\text { 1) Pembuatan akses jalur } \\
\text { pejalan kaki. } \\
\text { 2) Jumlah entrance perlu } 3 \\
\text { titik, terkait kenyamanan } \\
\text { jakan pejalan kaki } \\
\text { (Ujung barat, ujung } \\
\text { timur, dan tengah, } \\
\text { sehingga jarak tempuh } \\
\text { sekitar } 400 \text { m untuk jalan } \\
\text { kaki) } \\
\text { 3) Perlu drop off untuk } \\
\text { pengantar atau taksi on- } \\
\text { line } \\
\text { 4) Perlu tempat parkir } \\
\text { khusus sepeda, untuk } \\
\text { kendaraan bermotor } \\
\text { dapat parkir di area ruko. }\end{array}$ \\
\hline 2 & $\begin{array}{l}\text { Kelompok } \\
\text { Social } \\
\text { Pengguna \& } \\
\text { Aktivitasnya }\end{array}$ & $\begin{array}{l}\text { 5) Warga dengan usia balita } \\
\text { bersama orang tua } \\
\text { menggunakan di waktu } \\
\text { pagi dan sore hari } \\
\text { 6) Warga senior atau lansia } \\
\text { menggunakan di waktu } \\
\text { sore hari } \\
\text { 7) Warga pelajar dan } \\
\text { mahasiswa } \\
\text { menggunakan waktu } \\
\text { siang dan malam } \\
\text { khususnya apabila } \\
\text { terdapat jaringan internet } \\
\text { 8) Para ibu-ibu } \\
\text { menggunakan area }\end{array}$ \\
\hline
\end{tabular}

lapang untuk kegiatan zumba

9) Para bapak-bapak memanfaatkan tepi air untuk memancing

\begin{tabular}{lll}
3 & Kenyamanan & Desain harus memikirkan \\
Desain dan & kondisi fisik: (1) Topografi \\
Tema & lahan yang curam, (2) \\
& Skema desain responsif \\
& terhadap naiknya air saat \\
& musim hujan. \\
\hline
\end{tabular}

Kegiatan diskusi internal berupa simulasi FGD mengenai pembuatan peta pikiran bersama-sama, kemudian dilanjutkan dengan menterjelankan sejumlah kriteria tersebut kedalam sketsa gagasan. Pada tahap ini, tim PkM terdiri dari mahasiswa arsitektur yang telah terbiasa dengan mengungkapkan gagadsan lewat sketsa. Sehingga penentuan tema desain serta penerapan kriteria kenyamanan dan keamanan dapat dituangkan dengan baik dan lancar (Gambar 4).

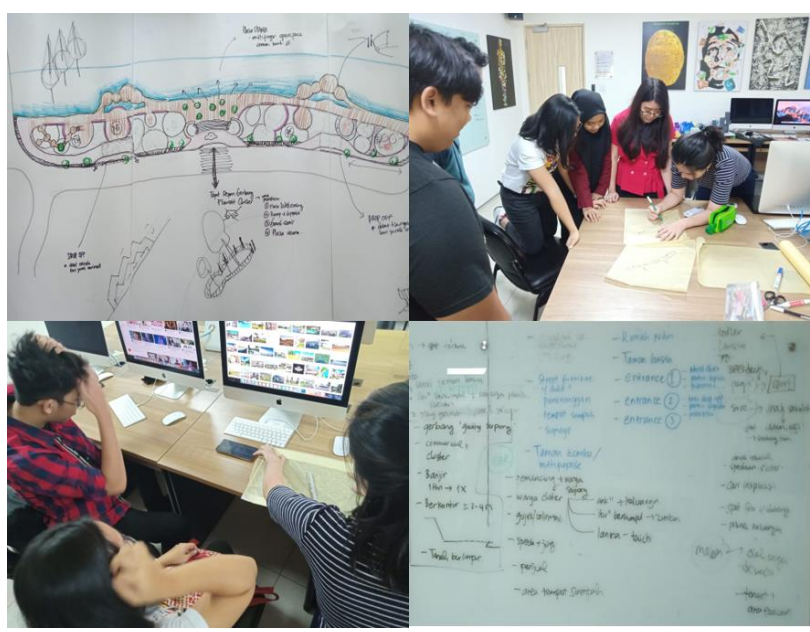

Gambar 4. Simulasi FGD oleh Tim PkM yang terdiri atas mahasiswa dan dosen

Dari persiapan tersebut, mahasiswa yang telah melaksanakan simulasi diharapkan dapat memandu sebagai fasilitastor bagi warga. Pada prakteknya, tim PkM akan berhadapan dengan warga langsung dengan berbagai latar belakang, sehingga perlu perencanaan lebih lanjut, apakah FGD perlu dibuat dapat bentuk sketsa dan maket sederhana, supaya gagasan desain adapat lebih muncul dan mudah dipahami. Sasaran FGD juga perlu dikerucutkan,

Lingkungan Hidup dan Bencana 
yaitu siswa Sekolah Dasar yang berada dekat dengan lokasi, dengan harapan fasilitator dapat menjembatani aspirasi warga melalui para anakanak. Dengan demikian informasi yang didapat lebih objektif sekaligus menerapkan rasa kepemilikan terhadap lingkungan sekitar bagi generasi muda.

\section{Pelaksanaan}

Pelaksanaan dilakukan pada masa Pandemi Covid 19, sehingga kegiatan PkM CSR ini masih terhenti di tahap awal dilaksanakan. Kegiatan FGD bersama warga masih ditunda dan akan dilaksanakan setelah keadaan kembali normal. Pelaksanaan pembangunan aksesibilitas diwujudkan dengan pembuatan jalur pejalan kaki yang menerus sepanjang area sempadan sungai. Pada Gambar 5 memperlihatkan ilustrasi potongan penampang jalan dari kondisi eksisting. Lebar sungai mencapai 36 meter hingga 66 meter, sepanjang $1 \mathrm{~km}$ berdampingan dengan jalan raya disampingnya. Terdapat topografi yang sangat curam sehingga daerah perancangan perlu diperhatikan batasannya.

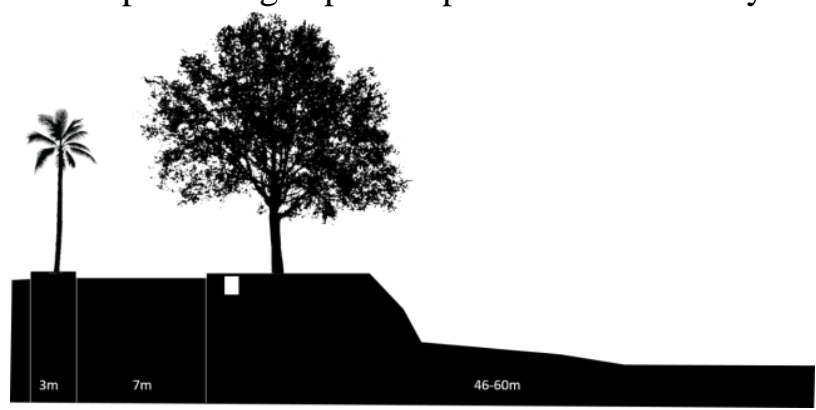

Gambar 4. Skema Potongan Melintang Eksisting di Tepi Sungai Cisadane

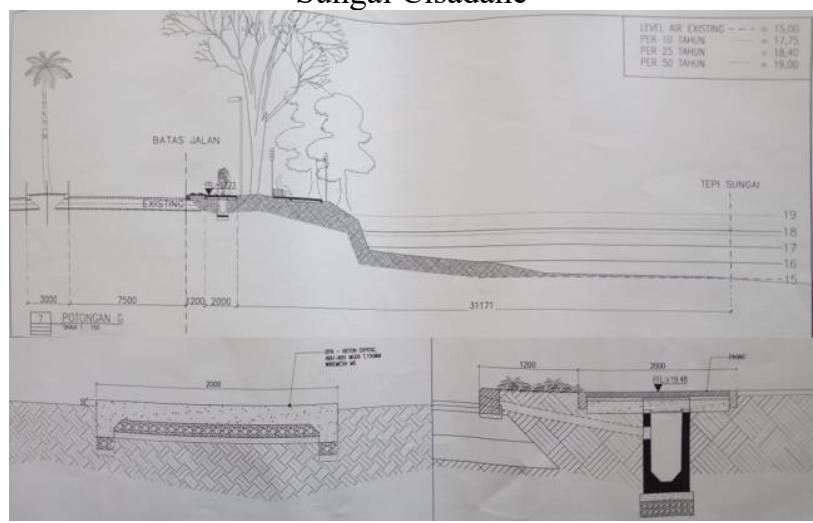

Gambar 5. Skema Potongan Melintang Perencanaan di Tepi Sungai Cisadane
Identifikasi ketinggin air untuk banjir tahunan dapat meningkat, seperti diperlihatkan pada Gambar 5, sehingga batasan hanya pada area dengan elevasi tertinggi. Selain itu, berdasarkan Permen PU No $5 \mathrm{Th}$ 2008 Pedoman Penyediaan dan Pemanfaatan RTH di Kawasan Perkotaan, menyebutkan bahwa ketentuan ruang vegetasi untuk sungai di kawasan permukiman berupa sempadan sungai yang diperkirakan cukup untuk dibangun jalan inspeksi antara 10-15 m. Jarak sempadan tersebut perlu diperhitungkan.

Pekerjaan pembangunan dikerjakan sepenuhnya oleh Tim CSR PT. Summarecon Agung. Material yang digunakan disesuaikan dengan perkerasan pada area Ruko Flourite yaitu dengan paving berwarna merah. Perbaikan jalur hidrologi kawasan juga dilakukan menggunakan saluran yang lebih besar untuk dapat menampung limpasan air hujan. Pada gambar 6 memperlihatkan proses pengerjaan pembangunan jalur Pejalan kaki. Terlihat beberapa kegiatan sudah terjadi di area ini, yaitu berhenti sejenak bagi pengendara motor dan juga tempat berhenti penjaja keliling. Dengan adanya jalur pejalan kaki ini diharapkan warga sekitar dapat memanfaatkan

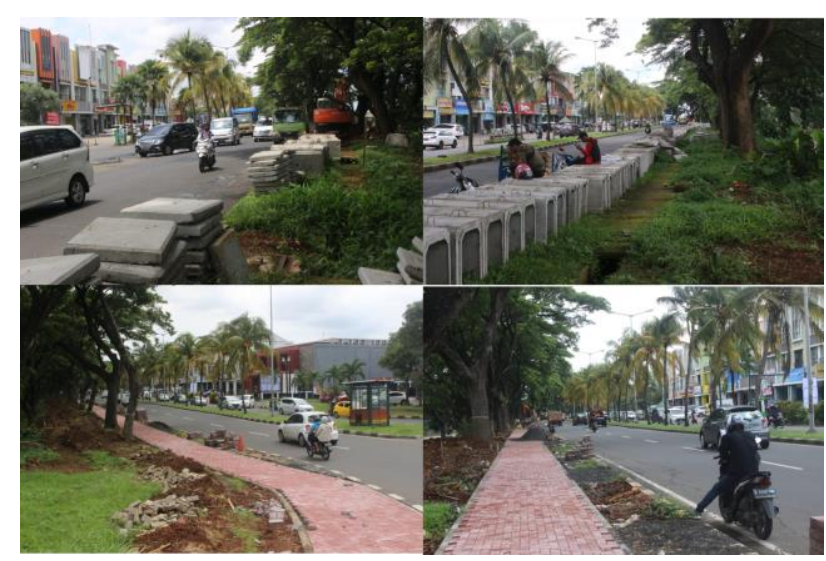

Gambar 6. Pekerjaan Pembangunan Jalur Pejalan Kaki

\section{Evaluasi}

Secara umum, tahapan awal dalam pelaksanaan kegiatan Pengabdian kepada Masyarakat telah terlaksana dengan baik, terbukti dari pembangunan area perkerasan bagi pejalan kaki sebagai bagian dari perencanaan aksesibilitas. Kualitas jalur pejalan kaki juga mencakup perbaikan jalur hidrologi bagi

$$
\text { Lingkungan Hidup dan Bencana }
$$


kawasan. Saat ini warga sekitar sudah dapat menggunakan fasilitas tersebut.

\section{KESIMPULAN}

Serangkaian kegiatan tahap awal Perencanaan Ruang Publik di Area Tepi Sungai Cisadane berupa Penyediaan Aksesibilitas bagi pejalan kaki sudah dilakukan dengan lancar atas dukungan dari berbagai pihak yang terlibat. Namun begitu, kegiatan ini tentunya masih jauh dari sempurna dan masih perlu untuk dilakukan pengembangan dan masukan yang membangun dalam kegiatan selanjutnya atau kegiatan mendatang.

Kegiatan ini merupakan kegiatan yang sangat diperlukan untuk mendukung kegiatan berkota bagi warga sekitar dan kemudahan akses dan konektivitas yang mendukung warga untuk berjalan kaki. Untuk itu, perlu dilakukan tahapan selanjutnya dengan perlibatan pihak akademisi dan praktisi.

\section{UCAPAN TERIMAKASIH}

Ucapan terima kasih kami tujukan untuk Tim CSR PT. Summarecon Agung, khususnya untuk pelaksana proyek kawasan Gading Serpong atas waktu dan kesediaannya bersama-sama melaksanakan kegiatan ini. Selain itu, ucapan terima kasih juga kami tujukan untuk Lembaga Penelitian dan Pengabdian Masyarakat (LPPM) Universitas Pradita yang mendanai pelaksanaan PkM ini.

\section{REFERENSI}

Rezeki, Sri. (2017). Penataan Ruang Terbuka Public Pada Bantaran Sungai Di Kawasan Pusat Kota Palu Dengan Pendekatan Waterfront Development. Desertasi. Surabaya: ITS

Peraturan Mentri Pekerjaan Umum No. 05/PRT/M/2008 tentang Pedoman Penyediaan dan Pemanfaatan Ruang Terbuka Hijau di Kawasan Perkotaan

The Code on Accessibility in the Built Environment 2019 